\title{
Obituary
}

European

Thyroid Journal
Eur Thyroid J 2018;7:109-110

DOI: $10.1159 / 000486368$

Published online: January 16, 2018

\section{In Memoriam: Gabriella Morreale de Escobar}

Prof. Gabriella Morreale de Escobar passed away in Madrid on December 4, 2017, at the age of 87 years. She was born in Milan, Italy, in 1930, attended elementary school in Vienna and Baltimore, and took the Baccalaureate in Malaga, Spain. She graduated in Chemistry and obtained the Doctor's degree from the University of Granada. Using an extremely laborious method for iodine measurement, she demonstrated that there was a good correlation between iodine content in water and urine and the incidence of goiter in the Alpujarras, a mountainous region near Granada. This was the start of a brilliant and influential scientific career together with her husband Prof. Francisco Escobar del Rey, who died in December 2015. They spent a postdoctoral stay in Leiden with Professor A. Querido, performing early studies on thyroid hormone metabolism using radioisotopes and returned to Madrid in 1958 as a staff of the High Council for Scientific Research (CSIC). In 1974, they moved to the Faculty of Medicine of the Autonomous University of Madrid where they were co-founders of the Instituto de Investigaciones Biomedicas.

Gabriella made unique and very influential contributions to thyroid pathophysiology. Early in her research, she used antithyroid drugs such as PTU to show that T4 had to be deiodinated for biological activity, which led to

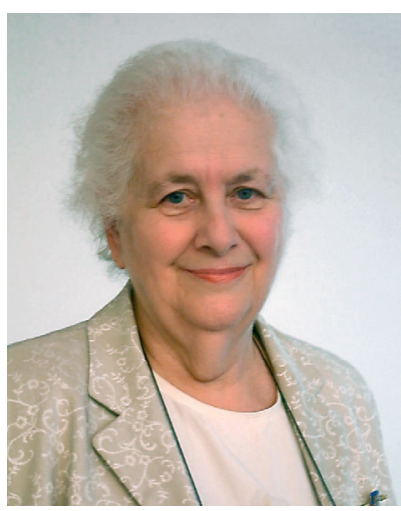

Gabriella Morreale de Escobar

the proposal that $\mathrm{T} 4$ is a prohormone and $\mathrm{T} 3$ the active hormone. She adapted very sensitive, specific radioimmunoassays for T4 and T3 for their detection in serum and tissues. This technique allowed the measurement of tissue T4 and T3 concentrations in many physiological settings, leading to the concept that individual tissues controlled the amounts of T3 needed by regulating its local formation from $\mathrm{T} 4$, and that this control was especially dramatic in the brain. Against the old thinking that the placenta was impermeable to thyroid hormones, she demonstrated that there is a transfer of thyroid hormones

\section{KARGER}

E-Mail karger@karger.com

www.karger.com/etj (c) 2018 European Thyroid Association

Published by S. Karger AG, Basel 
from mother to fetus from early gestational stages, and that maternal transfer of $\mathrm{T} 4$ is important for fetal brain development, raising the question that maternal hypothyroxinemia, and not maternal hypothyroidism, was detrimental to the fetus. In Spain, she initiated the screening program for early detection of congenital hypothyroidism and was instrumental in the introduction of iodized salt.

She was very active and influential in Spanish and international scientific societies. She was one of the founders of the European Thyroid Association, in 1967, and President from 1978 to 1980 . Among her many prizes and recognitions, she received the European Thyroid Association Prize in 1985 and the Serge Lissitzky Career Award in 2009. Several generations of scientists initiated their research in her laboratory. Gabriella was active many years after her official retirement and was a continuing source of inspiration.

Gabriella was not only an important and excellent leader in the field of thyroid research but also a very warm and wonderful person with an open and friendly character towards everybody. The entire thyroid community has expressed its condolences to an extraordinary scientist with a generous and exceptional personality. She will be missed at meetings in Europe and throughout the world; nevertheless, she has left a privileged legacy to all of us who have learned with her, and most important her spirit will always remain.

She is survived by her son, Dr. Hector Escobar-Morreale, and her two grandchildren, Inés and Francisco.

Juan Bernal, Maria Jesús Obregon, Pilar S. Santisteban 